\title{
Investigation of Constructivist Science Learning Environment in Thai Primary Schools
}

\author{
Pornpaka Chamnanwong \\ Chokchai Yuenyong*
}

\author{
Department of Science Education, Faculty of Education, Khon Kaen University
}

Email: ychok@kku.ac.th

\section{Doi:10.5901/mjss.2014.v5n27p592}

\section{Abstract}

The purpose of this study was to investigate the science learning environment in Thai primary schools by using the Constructivist Learning Environment Survey (CLES) which was originally developed by Taylor and Fraser (1991). Data were collected from 35 grade 5 students of Bannakanlueang School, Phu Wiang District, Khon Kaen province, Thailand by the CLES questionnaire and 10 hours classroom observations. Interviews with 1 participating teacher and the teachers' profiles were also made. Results from this study can be used planning teachers' professional development programs. The different cultures and contexts allowed us to learn how the socio cultural view affects classroom learning environments, and to get knowledge base for applying constructivist teaching into classroom. This may has implications for enhancing constructivist teaching in school context.

Keywords: Primary Schools, Constructivist Learning Environment Survey (CLES),

\section{Introduction}

The National Education Act, 1999 aims to develop Thai people into a complete human being. Physical and mental, intellectual and moral education must be based on the principle that all students are capable of learning and selfdevelopment. The National Education Act, 1999 are regarded as the most important lessons education should encourage the students to develop their natural and full of potential. In addition, the National Education Act, 1999 stipulated the way of education that education shall be based on the principle that every student has the ability to learn and develop themselves and believe in the student center. The education should encourage students to develop themselves in accordance with their natural and full of their potential (Office of the National Education Commission, 1999). Likewise, the Institute for the Promotion of Teaching Science and Technology; IPST (2002) introduced the concept of science teaching today; science teaching emphasized the process that the most important is students learning by themselves and teachers will serve as the only event for students to learn on their own rather than be told the students to remember with a regard of maturity and their own experiences and environments before entering the classroom. So, to education in accordance with the Education Act, the classes should be the constructivist classrooms.

The constructivist view has become the leading theoretical position in education and has been the most powerful driving force in science and mathematics education, particularly during the past decade (Bransford et.al., 2000; Duit \& Treagust, 2003; Steffe \& Gale , 1995; Tobin, 1993). At the heart of constructivism, Duit and Treagust (1995) proposed the idea that knowledge about the world outside is viewed as human construction. A reality outside the individual is not denied; rather, it is claimed that all we know about reality is only our tentative construction. Accordingly, learning is not viewed as transfer of nuggets of truth but as active construction. It is the learner who constructs, or even creates, his or her knowledge on the basis of the knowledge already held. In addition, there are social aspects of the construction process; although individuals have to construct their own meaning of a new idea, the process of constructing meaning is always embedded in a particular social setting of which the individual is part. If a communication situation between a student and a teacher is considered from the constructivist viewpoint, it is apparent that there is a cycle of understanding that is well known from pedagogy. The students have a meaningful knowledge through discussion, negotiation and bargaining reasons. During the discussion of specific distributions and they can make his ideas more clearly, and thus, there's an exchanging of ideas. Listening, reflecting students from other reflect the concept of self critical to exchange ideas will help students restructure ideas and meaning (McRobbie and Tobin, 1997) in teaching and learning activities in science classrooms another paragraph.

The Constructivist theory and critical theory have been combined to create a powerful interpretive framework for 
examining science teaching. The lack of knowledge about NOS of teachers and students leads to: passive learning style/ students are afraid of making mistake, hard for students to use school knowledge in everyday situation, decrease students' promotion enthusiasm in learning science. Learning NOS is very important in constructivist classroom

The original version of the CLES was based on a theory of constructivism that underpins recent research in science and mathematics education that is concerned with developing teaching approaches that facilitate students' conceptual development (Driver, 1989). This conceptual change research highlights: (1) the key role of students' prior knowledge in their development of new conceptual understandings, especially the problematic role of students' alternative conceptions; and (2) the reflective process of interpersonal negotiation of meaning within the consensual domain of the classroom community.

However, our research on teachers' development of constructivist pedagogies has shown how readily traditional teacher-centered classroom environments can assimilate conceptual change perspectives and remain largely unchanged (Taylor, 1992, 1993, 1994). We have found that the rationality of traditional teacher-centered classrooms is dominated by two cultural myths: (1) an objectivist view of the nature of scientific and mathematical knowledge; and (2) a complementary technical controlling interest? that views the curriculum as a product to be delivered. If classroom learning environments are to feature negotiation and meaning-making, then teachers need to be empowered to deconstruct these repressive myths.

Nowadays, Thai education run through this education law for twelve years apart but we do not exactly sure Thai education context is constructivist based learning or not. According to this argument we would like to investigate constructivist learning in science classroom. Therefore, Constructivist Learning Environment Survey (CLES) was selected in this study. The CLES (Taylor, Fraser, \& Fisher, 1997) was the instrument that helps teachers and researchers to evaluate the degree of a particular classroom's environment which consist with a constructivist epistemology, and helps teachers to reflect on their epistemological assumptions and recast their instruction.

The main purposes of this study are:

To investigate the use of an existing instrument, the Constructivist Learning Environment Survey (CLES), for providing information of the classroom learning environments of beginning science teachers.

\section{Methodology}

\subsection{Method}

This research made use of qualitative paradigms: a qualitative paradigm used interpretive analysis. Interpretive research explores to explain and interpret human behavior derived from their natural setting rather than form laws about it (Marriam, 1998;). The paper adapted the Constructivist Learning Environment Survey (CLES) is being used in the present study to assess both teachers' and students' perceptions of classroom learning environments actual and preferred forms, observation and interview to investigate the learning environment in learning of science classrooms at Bannakanlueang School, Phu Wiang District, Khon Kaen Province, Thailand as well as to illustrate the teachers' opinions from the perspective of constructivist.

\subsection{Participant}

The participants were consist of Grade 5 students, and Chan science teacher at Bannakanlueang School, Phu Wiang District, Khon Kaen. The samples were 35 Grade 5 students and a female science teacher in her 48 years old age. She has the experiences in science teaching for 10 years.

\subsection{Instruments}

There are two instruments including classroom observation and interview. The classroom observation aimed to examine constructivist learning environment. The framework of observation regarded on Taylor et al. (1997)'s constructivist Learning Environment Survey (CLES) observation. This classroom observation called the CLES observation. The interviews were applied to probe further what teacher and students did in classroom regarding on the CLES. Table 1 is a brief summary of the key issues of the CLES, which were taken from Taylor et al. (1997). 
Table 2: Scales, Scale Descriptions and Sample Items of the CLES, taken from Taylor et al. (1997).

\begin{tabular}{|c|c|c|}
\hline Scales & Scale description & Item Sample (Actual form) \\
\hline $\begin{array}{l}\text { Personal } \\
\text { relevance }\end{array}$ & Extent to which teachers relate science to students out of school experiences. & $\begin{array}{l}\text { In this class, I learn about the } \\
\text { world outside of school. }\end{array}$ \\
\hline $\begin{array}{l}\text { Scientific } \\
\text { uncertainty }\end{array}$ & $\begin{array}{l}\text { Extent to which opportunities are provided for students to experience scientific } \\
\text { knowledge as arising from theory dependent inquiry. }\end{array}$ & $\begin{array}{l}\text { In this class, I learn that science } \\
\text { has changed over time. }\end{array}$ \\
\hline Critical voice & $\begin{array}{l}\text { Extent to which a social climate has been established in which students feel that it } \\
\text { is beneficial to question the teacher's pedagogical plans and methods to express } \\
\text { concerns about any impediments to their learning. }\end{array}$ & $\begin{array}{l}\text { In this class, It's OK for me to } \\
\text { ask the teacher 'Why do I have } \\
\text { to learn this?' }\end{array}$ \\
\hline $\begin{array}{l}\text { Shared } \\
\text { control }\end{array}$ & $\begin{array}{l}\text { Extent to which students are invited to share with the teacher control of the } \\
\text { learning environment. }\end{array}$ & $\begin{array}{l}\text { In this class, I help the teacher } \\
\text { to plan what I'm going to learn. }\end{array}$ \\
\hline $\begin{array}{l}\text { Student } \\
\text { negotiation }\end{array}$ & $\begin{array}{l}\text { Extent to which opportunities exist for students to explain and justify to other } \\
\text { students their newly developing ideas. }\end{array}$ & $\begin{array}{l}\text { In this class, I talk with other } \\
\text { students about how to solve } \\
\text { problems. }\end{array}$ \\
\hline
\end{tabular}

The preferred form have similar statements as in the actual form, with the phrase "would preferred" were added.

The theoretical framework of constructivist classroom learning environment regarded Taylor, Fraser, and White (1994)'s constructivist learning environment framework. Taylor et. al. (1994) provided the Constructivist Learning Environment Survey (CLES) based on five dimension of constructivist teaching. These included Personal Relevance (PR), Student Negotiation (SN), Shared Control (SC), Critical Voice (CV), and Uncertainty (UN) (Taylor, Fraser, \& White, 1994;Taylor,1991; Taylor, \& Fisher, 1997).

Personal Relevance (PR) focuses on the connectedness of school science to students' out-of-school experiences, and with making use of students' everyday experiences as a meaningful context for the development of students' scientific and mathematical knowledge.

Uncertainty(UN) refers to the extent to which opportunities are provided for students to experience scientific knowledge as arising from theory-dependent inquiry involving human experience and values, and as evolving, nonfoundational, and culturally and socially determined.

Critical Voice (CV) examines the extent to which a social climate has been established in which students feel that it is legitimate and beneficial to question the teacher's pedagogical plans and methods, and to express concerns about any impediments to their learning.

Shared Control (SC) is concerned with students being invited to share with the teacher control of the learning environment, including the articulation of learning goals, the design and management of learning activities, and the determination and application of assessment criteria.

Student Negotiation (SN) is scale assesses the extent to which opportunities exist for students to explain and justify to other students their newly developing ideas, to listen attentively and reflect on the viability of other students' ideas and, subsequently, to reflect self-critically on the viability of their own ideas.

\section{Data Collection}

The description of method and data collection was explained concerning on the audit trailing. The science teacher, being called Chan in this paper, taught in the classroom that we observed. She was explained the aim of the research. The CLES observation and interviewing were applied to interpret Chan's classroom constructivist learning environment. Data collection was carried out for three weeks. The CLES observation and interview were done one time a week. The CLES interview was done after classroom observation.

\section{Data Analysis}

The CLES observation and interview provided the lens of constructivist learning environment. The teacher and students' discourses, and students' tasks were interpreted and categorized regarding Taylor, Fraser, and White (1994)'s CLES theoretical framework. The think description and peer debriefing were considered for creditability.

\section{Results and Discussion}

Grade 5 primary school classrooms could be clarified constructivist learning environment regarding to the CLES 
framework. Therefore, the aspects of personal relevance (PR), uncertainty (UN), critical voice (CV), shared control (SC), and student negotiation (SN) will be examined.

\subsection{Personal Relevance}

Personal relevance: focuses on the connectedness to students' out-of-school experiences, and with making use of students' everyday experiences as a meaningful context for the development of students' scientific knowledge. Classroom observation revealed that Chan realized that the out-of-school experiences were important to help her students know how to apply the school knowledge to their daily lives. She tried to raise examples related to everyday life. For an example, she taught electrical conductor in classroom and then asked students to observe electrical materials in their houses, which one should be conductor or insulator. However, she focused more on the content rather than applying scientific concepts for communicating in everyday life. And, it seemed that Chan had difficulty to apply theory into practice. Her interviewing indicated that she was aware of the importance of students' outside school experiences but she could not often teach science related students' experiences. It's probably she knew a few of teaching strategies for linking science teaching to every life as discourse below. She could not link provided scientific concepts in textbook into everyday life experiences. For example learning about insulation, she assigned students to read the information from textbook instead of doing experiment about insulation or investigating kinds of insulation from students' house or everyday experiences.

Interviewer: Do you often create opportunities to let your students learn about the world outside of school? Chan: "Rarely, I know it is important to let your students learn about the world outside of school,but when students leave the classroom, I cannot take care of them" "I focus on the content of the lesson.

Interviewer: Do you often start a new learning with problems or experiences about the world outside of school?

Chan: "Yes, I often start a new learning with problems or experiences about the world outside of school. Because I think my students can easily understand when I teach them. But I want to teach the content of the lesson before that. I think my students will be benefit from starting a new learning in this way."

Interviewer: Do you think that it is important to help your students know how to apply the school knowledge to their daily lives?

Chan: "Yes, It is important to help my students know how to apply the school knowledge to their daily lives. I think that everything that they learn in school will be used in everyday life. When I teach them, I asked them about its use in everyday life."

Interviewer: Does your lesson involve some interesting things about the world outside of school?

Chan: "I think in some content such as plants and animal, there are some interesting things about the world outside of school. When I teach my students I used instructional questions so that they practice and observe. I will give them notice of the difference in species of plants outside the classroom."

\subsection{Scientific Uncertainty}

Uncertainty: The examines the extent to which opportunities are provided for students to experience scientific knowledge as arising from theory-dependent inquiry involving human experience and values, and as evolving, nonfoundational, and culturally and socially determined. Chan 's classroom observations indicated that she could not recognize the human experience, values, culturally and socially determined in science for providing her classroom activities. She focused on scientific knowledge in the textbook. Her classroom environment was happened as mentioned earlier may related to her misunderstood on many aspects of the nature of science. This could be seen as her discourse below in which she thought that science: cannot be changed; is able to answer any questions; and is not influenced by peoples' cultural values and opinions.

Interviewer: Do you let your students learn that science cannot always provide answers to problems?

Chan: "No I don't .But I think sometimes I want my students find the answer themselves. I think scientific knowledge has always been able to answer the question."

Interviewer: Do your students learn that sciences (include theories, laws, concepts, explanations...) have changed over time?

Chan: "No, I don't. I think that sciences have not changed over time."

Interviewer: Do your students learn that science is influenced by people's cultural values and opinions?

Chan: "No, I don't. I think science is not influenced by people's cultural values and opinions. Science is learning about the advances in technology and learning about the fact that can be proved.."

Interviewer: Do you think that it will enhance students' outcome if they learn that science is a way to raise questions and seek answers?

Chan: "Yes I do. I know it is important for student learning by raising raise questions and seeking answers. Sometime I 
used question approach for students to finding their own answers."

\subsection{Student Negotiation}

Student Negotiation: assesses the extent to which opportunities exist for students to explain and justify to other students their newly developing ideas, to listen attentively and reflect on the viability of other students' ideas and, subsequently, to reflect self-critically on the viability of their own idea. It seemed that she wants students develop new idea by themselves but the students aren't involved in the planned lesson. She has the plan for student construct knowledge by themes. Chan tried to enhance students' discussion through her questioning. She tried to probe students' ideas and raise the issues the related to scientific concepts regarding to textbook and ask for students' thinking. However, the majority of students kept quiet. It seemed that students were waiting for the correct answers from teacher. This may related to her role in the classroom. She normally tried to explain scientific knowledge as the fact provided in textbook rather than probe students to construct the meaning of those concepts. She reflected as follow:

Interviewer: Do your students often talk with other students about how to solve problems?

Chan: "Yes I do. When my student they have problem and they talk about to solve problems I let them speak first, and when he did not find the answer to your problems. I'm going to help now. And sometimes I told them 'ask me when you have problem, don't ask your friend'."

Interviewer: Do your students often explain their ideas to other students?

Chan: "Yes I think that sharing ideas among students is important and I encourage them to share their ideas. But it is very rare for them to talk about their ideas. Most of them are waiting to hear from teachers."

Interviewer: Do your students often ask other students to explain their ideas?

Chan: "No they don't. I think that it's important when students ask other students to explain their ideas I encourage them to ask for the others' explanation."

Interviewer: Do your students often explain their ideas to each other?

Chan: "I think that when students explain their ideas to each other, they will learn better. I support and encouragement and praise for what they do.

\subsection{Critical Voice}

Critical voice: The examines the extent to which a social climate has been established in which students feel that it is legitimate and beneficial to question the teacher's pedagogical plans and methods, and to express concerns about any impediments to their learning. Chan science classroom's observation refer to the students aren't involved in the planned lesson. She has been serious about content. When she taught, she focused only content and not allow students ask questions in addition to the lessons. The classroom environment did not show critical voice when she do not give students the opportunity to express them ideas by the students cannot get up on time and she thought that better learning by using textbook. She reflected as follow:

Interviewer: Have your students ever questioned the content and the way they are being taught?

Chan: No they do not. I think it will not helpful if students question the content and the way they are being taught."

Interviewer: Do you think that your students learn better when they are allowed to question what or how they are being taught?

Chan: "I had planned to teach them, when I let the students design their own learning it. Interviewer: How often your students ask you to clarify the activities that are confusing?

Chan : "Sometimes, there are some activities that my student are confusing such as energy, when they ask me about the activities that confusing I think it will be helpful for them. It will help them to understand them better."

Interviewer: How often your students express their concern about anything that obstructs them from their learning?

Chan: "Rarely, because I will try to explain each detail about the content they are learning. I think it will be helpful if students express their concern about anything that obstructs them from their learning and they ask me those things."

\subsection{Shared control}

Shared Control: Students can being invited to share with the teacher control of the learning environment, including the articulation of learning goals, the design and management of learning activities, and the determination and application of assessment criteria. Observation in the classroom of Chan showed that the students did not have opportunities to take part in introduction, explaining experimental results and discussing collected data. Chan showed limited experience to shared and organize classroom. She did not provide issues to share and design for student help in assessment and management of learning activity in class. The method of the teacher did not support the constructivist learning paradigm. Results from the interview can be reflected as following: 
Interviewer: Have you ever let the students help you to plan what they are going to learn? Chan: No, I think that it will not be helpful if my students help me to plan." Interviewer: Have you ever let the students help you to decide how well they are learning? Chan: No, I think that it will not be helpful if students help me to decide how well they are learning." Interviewer: Have you ever let the students help you to decide which activities work best for them? Chan: "No, I think that it will not be helpful if my students help me to decide which activities work best for them." Interviewer: Do your students often let you know if they need more/less time to complete an activity? Chan: "Sometimes they feel that it is an activity that is difficult, but there is less time to do things. Sometimes I agree with them and I use explanation to save time."

\section{Conclusion}

The study found that schools, parent network, teachers and students should cooperate in improving and learning based on constructivist is more practical and construct new sustainable culture of learning based on constructivist.

However, when considering opinions about learning environments under the context of Thai curriculum, it was found that students had decided to participate in learning activities at low degree. Teachers should encourage or stimulate students to participate in learning decisions such as activity planning in the classroom, learning design, evaluation of activities, and reasoning in considering the activities of teaching and learning in the classroom such as timing the activities, specifying the content of the course, defining problems in learning and so on.

\section{References}

Bransford, J., Brown, A., \& Cocking, R. (2000). How People Learn: Brain, Mind, and Experience \& School. Washington, DC: National Academy Press.

Driver, R. (1989). Students' conceptions and the learning of science. International Journal of Science Education, 11(5): 481 - 490.

Duit R. and Treagust D.F., (1995), Students' conceptions and constructivist teaching approaches. In B.J. Fraser and H.J. Walberg (Eds.), Improving science education, The National Society for the Study of Education, Chicago, IL, pp. 46-49.

Duit, R., \& Treagust, D. (2003). Conceptual change: a powerful framework for improving science teaching and learning. International Journal of Science Education, 25, 671-688.

Institute for the Promotion of Teaching Science and Technology (IPST). (2002). The Manual of content of science learning. Bangkok, Thailand: Curusapha ladphoa.

Merriam, S. B. (1998). Qualitative Research and Case Study Applications in Education. Revised and Expanded from "Case Study Research in Educatio. San Francisco: Jossey-Bass Publishers.

McRobbie, C. \& Tobin, K. (1997). A social constructivist perspective on learning environments. International Journal of Science Education, 19(2), 193-208.

Office of the National Education Commission. (1999). "The National Education Act of 1999, as amended (no.2) of 2002". Bangkok: Auksornthai. 13-16.

Steffe, L.P. and Gale, J. (1995). Constructivism in Education. New Jersey : Lawrence Erlbaum Associates, Inc.

Taylor, P.C. (1992). An interpretive study of the role of teacher beliefs in the implementation of constructivist theory in a secondary mathematics classroom. Unpublished doctoral thesis. Curtin University, Perth, Australia.

Taylor, P.C. (1993). The influence of researcher beliefs on constructivist teaching practice. In K. Tobin (Ed.), The practice of constructivism in science and mathematics education (pp. 267-297). Washington, DC: American Association for the Advancement of Science.

Taylor, P.C. (1994b, Dec). Collaborative classroom-based action research: Persuasion or coercion? Paper presented at the symposium on Contemporary Approaches to Research in Mathematics, Science and Environmental Education, Deakin University, Burwood, Victoria.

Taylor, P.C., \& Fraser, B.J. (1991). CLES: An instrument for assessing constructivist learning environments. Paper presented at the annual meeting of the National Association for Research in Science Teaching, The Abbey, Fontane, Wisconsin.

Taylor, P.C., Fraser, B.J, \& Fisher, D.L. (1997). Monitoring the development of constructivist learning environments. International Journal of Educational Research, 27(4), 293-302

Taylor, P.C., Fraser, B.J. \& White, L.R. (1994, April). The revised CLES: A questionnaire for educators interested in the constructivist reform of school science and mathematics. Paper presented at the annual meeting of the American Educational Research Association, Atlanta, GA.

Tobin, K.(1993). The practice of constructivism in science and mathematics education. Washington, DC: American Association for the Advancement of Science. 


\section{Appendixes A}

Items in Constructivist Learning Environment Survey (CLES)

1. Learning About the World

1. Students learn about the world outside of school?

2. New learning starts with problems about the world outside of school?

3. Students learn how science can be a part of their out-of-school life?

4. Students get a better understanding of the world outside of school?

5. Students learn interesting things about the world outside of school?

6. What students learn has nothing to do with their out-of-school life?

2. Learning about Science

7. Students learn that science cannot provide perfect answers to problems?

8. Students learn that science has changed over time?

9. Students learn that science is influenced by people's values and opinions?

10. Students learn that different sciences are used by people in other cultures?

11. Students learn that modern science is different from the science of long ago?

12. Students learn that science is about inventing theories?

3. Learning to Speak

13. It's OK for students to ask me "Why do we have to learn this?"

14. It's OK for students to question the way they are being taught?

15. It's OK for students to complain about activities that are confusing?

16. It's OK for students to complain about anything that stops them from learning?

17. It's OK for students to express their opinion?

18. It's OK for students to speak up for their rights?

4. Learning to Learn

19. Students help me to plan what they are going to learn?

20. Students help me to decide how well they are learning?

21. Students help me to decide which activities are best for them?

22. Students have a say in deciding how much time they spend on an activity?

23. Students help me to decide which activities they do?

24. Students help me to assess their learning?

5. Learning to Communicate

25. Students get the chance to talk to other students?

26. Students talk with other students about how to solve problems?

27. Students explain their ideas to other students?

28. Students ask other students to explain their ideas?

29. Students are asked by others to explain their ideas?

30. Students explain their ideas to each other? 